DOI https://doi.org/10.18551/rjoas.2017-06.15

\title{
THE DETERMINANT OF PERCEIVED EASE OF USE AND ITS EFFECTS ON THE INTENTION TO USE OF WEBSITE-BASED INFORMATION TECHNOLOGY USER ON SMES OF FASHION SUB SECTOR CREATIVE INDUSTRY IN MALANG
}

\author{
Utama Satria*, Suyadi Imam, Mawardi Mukhamad Kholid \\ Master's Program of Business Administration, Faculty of Administrative Science, \\ University of Brawijaya, Indonesia \\ *E-mail: rd.saut28@gmail.com
}

\begin{abstract}
This research aimed to find out to what extent the readiness of creative industrial UMKM of fashion sector in Malang on the use of website-based Information Technology. The model proposed in this research was a combination between technology readiness and technology acceptance model, along with perceived enjoyment. These three variables were arranged to be one model and tested using the basic theory on the previous research. Based on the appointed variables and the designed hypotheses, this research belonged to explanatory research. The research used 30 distros/clothing stores in Malang city as the samples and the data analysis was done by using GSCA. The analysis result indicated that variables of discomfort and insecurity had a negative impact on perceived ease of use.
\end{abstract}

\section{KEY WORDS}

SMEs, technology readiness, technology, acceptance model, perceived enjoyment.

Nowadays, the development of Information and Communication Technology (ICT) enables product promotion done more easily through viral. This is one of the important strategies to increase the promotion of the product/service produced by UMKM. ICT is a media that can be used to build business networks, expand the business scale, increase production efficiency, and lead companies to a larger business system. Furthermore, ICT has become a supporting tool in developing competitive advantages of companies. However, on another side, the IT level of UMKM is still relative low. This is not only due to the factor of limited capital and resource owned by UMKM but also because of the UMKM's unpreparedness to adopt it. In fact, as the information and communication technology continues to grow, business transaction via the internet has also developed in line with the increased ease, comfort, and security provided in communication and transaction (Thong, 1999). The problem on the readiness to adopt IT is expected to be one of the reasons causing the low adoption level by UMKM that leads to the low competitiveness in the global market.

The lack of understanding on the use and easiness of IT as well as the readiness in adopting it is thought to be the underlying reason for the low adoption level by UMKM that eventually results in a decreased competitiveness in the global market. The benefit of the use of IT has been much known by the actors of UMKM, although its benefit does not necessarily encourage the actors to apply it to their businesses. Besides, there has not been a few actors who fail in applying the use of IT on their businesses. This is due to the improper use that does not make any result or change on the businesses. The adoption of IT in UMKM is different from that in big industries because of the limited resource owned by the UMKM (Fink, 1998; Thong, 1999; Welsh and White, 1981). Hence, UMKM must be careful in deciding IT investment.

The competitiveness of UMKM actually can be realized by many ways, one of which is by the use of IT in improving the competitiveness of business transformation as well as the accuracy and efficiency of information exchange (Rahmana, 2009) for widening the marketing networks and market share. The benefit of IT use has been much known by the actors of UMKM, but it does not necessarily motivate the actors to use it on their businesses. Therefore, understanding the user readiness in adopting the new technology is highly 
important to minimize the risk in the process of technology adoption. Several. researchers stated a fact saying that IT adoption in UMKM has still been extremely low from what has been expected (Pavic, et al., 2007; Yu, 2006). Furthermore, according to a research done by Lefebvre, et. al. (1999), one of the determinants of new technology adoption by UMKM is the influence of internal and external parties in the process of adoption-decision taking. Grounding by that fact, this research was conducted in order to deepen on the effects of the adoption decision. Hence, this further research was carried out to examine the underlying reasons for the UMKM's low IT adoption by using Optimism, Innovativeness, Discomfort, Insecurity, and Perceived Enjoyment as the determinants of the readiness of IT adoption by UMKM.

The focus of this research is on the 'perceived ease of use'. This has become an interesting issue regarding what extent the users' perception of IT. Their perceptions on the ease of IT use are different and this results in the 'intention to use' on a technology through five influential factors. The existence of IT actually gives many benefits for the users, but the 'intemtion to use' IT cannot suddenly emerge in users' minds. The intention to use IT has encouraged the researchers to conduct an observation or examination on someone's intention in using IT.

Davis (1989) examined on the technology acceptance by using Technology Acceptance Model (TAM) which was learned from the Model Theory of Reasoned Action (TRA) developed by Ajzen (1980) as the grand model of TAM development. The model of TRA developed by Ajzen (1980) assumed that human behavior was encouraged by the intention, attitude, belief which were influenced by subjective norms for doing something consciously. Contrastly, David, et al.(1989) stated that, in TAM, the real use of the system on an individual was determined by behavioral intention, which was influenced by perceived usefulness and perceived ease of use. Based on the result of the development, Davis (1989) argued that the effect of other external variables on the behavioral intention was fully mediated by two convictions, namely usefulness and ease of use.

Up until now, the focus of TAM in completing tasks is only on the question about the effectiveness and utility of a system (Jogiyanto, 2007). The development on TAM is carried out by various ways, such as adding, reducing, changing with other variables or combining TAM with other theory models. This has given a variation on the technology acceptance model (TAM). By this fact, Kim, Chan, and Gupta (2007) conducted a research in which TAM was developed by including another variable in the form of perceived enjoyment, which determined the acceptance of a technology. In another side, a research done by Shin and Lee (2014) concerned on the TAM development which was made by combining TR and including some variables such as optimism, innovativeness, discomfort, insecurity, along with the variable of technology characteristic consisting of responsiveness and smartness. And it turns out that the result is better for measuring the acceptance of electronic service.

\section{THEORETICAL REVIEW}

Theory Acceptance Model (TAM). TAM is a theory related to the use of information technology system that can be applied to explain the individual acceptance toward the use of information technology system itself. The theory is firstly presented by Davis (1986), which basically is the development of Theory of Reasoned Action (TRA) by Ajzen and Fishbein (1980). TAM adds two constructions of TRA model. The two construction are perceived usefulness and perceived ease of use. The argumentation of TAM is that the individual acceptance toward information technology system is determined by those two constructions. Both constructions will make attitude have an influence on behavior which then leads to behavioral intention - the basis of behavior done by an individual.

Technology Readiness (TR). TR is used to know a society tendency for having and using new technology in a house or workplace. Optimism and innovativeness are the contributors which can increase the readiness of technology application. Optimism is defined as a positive view of technology and positive perception of the utility of technology application in order to increase the work efficiency as well as to improve the user's 
performance either in the workplace or house. Innovativeness refers to what extent someone excitedly does experiment with a technology and becomes a pioneer or forefront in a new technology-based product/service business. Meanwhile, discomfort and insecurity refer to inhibitors which can press the readiness of technology acceptance. Discomfort indicates a lack of mastery of technology application and lack of confidence in using new technology. Insecurity is a distrust of technology-based transaction and a doubt on the ability and security of a technology (Pasuraman and Colby, 2001).

Conceptual Model. The conception of this research is the result of the combination between TAM and TR or what, in several studies, has been called as TRAM, in which variable TR is put as the factor influencing and adding the variable of perceived enjoyment, and then simplified by emphasizing on the aspect of perceived ease of use in the context of TAM. Perceived ease of use concerns on to what extent someone believes that the use of technology is free from any efforts. Perceived ease of use establishes the relation of individual assessment on the efforts done in the process of using a system (Davis, 1989). Perceived ease of use is hereafter associated with the intention in TAM, which aims to predict the usage behavior.

TR has four sub-dimensions: optimism, innovativeness, discomfort, and insecurity (Parasuraman and Colby, 2000). In general, optimism and innovativeness are the contributors or positive motivators that can increase the readiness of technology use, while discomfort and insecurity are the inhibitors that can press the readiness of technology and as the hampering factors of new technology acceptance.

Perceived enjoyment, adopted from Davis, et al., (1992) refers to what extent the activity of a certain system application is considered enjoyable in an individual's mind. And it has formed the model as seen from Figure 1.

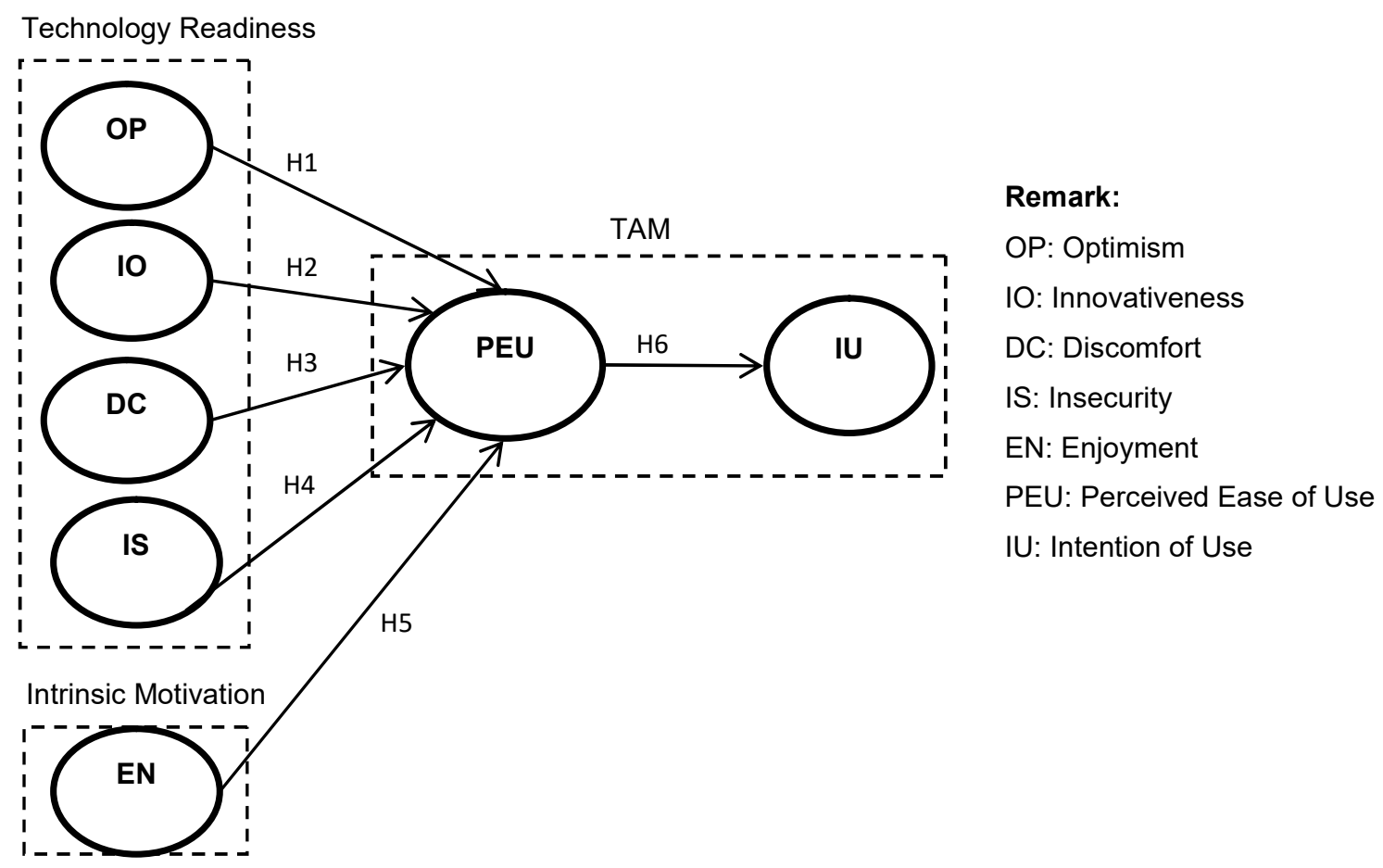

Figure 1 - The Schema of Research Model

Hypotheses. Optimism is an individual tendency in which a situation and condition are seen from its benefit or positive side that can bring out a more positive attitude on a computer. According to Walchuzh, et al. (2007), the employees' optimism significantly had a positive impact on perceived ease of use.

$\mathrm{H} 1$. Optimism has a positive effect on perceived ease of use 
It is known that a customer who thinks optimistically and innovatively on new technology has a tendency to express a positive attitude toward new technology. Lam, Chiang, and Parasuraman (2008) found that consumer's innovation and society behavior had a positive relation to the use of internet service. Moreover, Walchuzh, et al. (2007) stated that someone's innovativeness significantly had a good impact on the perceived ease of use. This research revealed that the managers or employees of creative industrial UMKMs who had innovative characteristic would perceive/assume the ease of IT use.

$\mathrm{H} 2$. Innovativeness has a positive effect on perceived ease of use

A user who feels uncomfortable (discomfort) in using a technology will think more complex when using it. Lam, et al. (2008) found that discomfort had a negative effect on the time span needed by a consumer to accept the internet and its ease of use. Similarly, Godoe and Johansen (2012) found that there was a negative relation between discomfort and perceived ease of use.

H3. Discomfort has a negative effect on perceived ease of use

Security is an essential matter for consumers who want to use new technology, particularly in a financial transaction. A user's insecurity commonly emerges due to the matter of his own security or privation. This will lead to an individual closed attitude toward a new technology and decrease the perceived ease of use in using technology. An empiric study done by Walchuzh, et al. (2007) found that security had a negative effect on perceived ease of use.

H4. Insecurity has a negative effect on perceived ease of use

Enjoyment is defined as the extent to which the activity of using a system or technology is considered enjoyable for the users. Hence, the perceived ease of use will certainly be influenced by the system on which users feel enjoyable when using it (Venkatesh, 2000; Venkatesh, et al., 2002). Furthermore, Venkatesh (2000) indicated that perceived ease of use was influenced by to what extent people perceive/assume that using a system was an enjoyable activity. Thus, it can be seen that perceived enjoyment can give a significant effect on users' perceived ease of use. It results in a hypothesis saying that:

H5. Enjoyment has a positive effect on perceived ease of use

In TAM, a behavioral intention to use a system is defined by the users' adoption attitude, including perceived ease of use and perceived usefulness. Perceived ease of use is also assumed to influence perceived usefulness, which is based on the idea saying that the increased ease of use can contribute to enhancing the usefulness (Davis, et al., 1989). An individual will have the intention to use IT when assuming that the IT is easy to use.

H6. Perceived ease of use has a positive effect on intention to use.

\section{METHODS OF RESEARCH}

This research used survey method by having questionnaires as the primary tool for data collecting with a quantitative approach. Viewed from the variables and hypotheses model used, it can be said that this research is an explanatory research. The number of the samples used is equal to the number of the population which was about 30 distros/clothing stores. The research location was in Malang city and the purposed objects were distros and clothing stores which either had used websites or not yet. GSCA was used for the testings of the instrument (construct validity and reliability) and hypotheses on the data that have been obtained through questionnaires.

\section{RESULTS AND DISCUSSION}

The Goodness Test Results of Fit Model. The structural model of this research was obtained from the result of data processing using the software of GeSCA. The goodness of Fit Model is beneficial for knowing whether a structural model is good or not, by seeing the value of FIT and AFIT as shown in Table 1. 
Table 1 - Goodness of Fit Model

\begin{tabular}{|c|c|}
\hline \multicolumn{2}{|c|}{ Fit Model } \\
\hline FIT & 0.735 \\
\hline AFIT & 0.634 \\
\hline GFI & 0.571 \\
\hline SRMR & 0.621 \\
\hline
\end{tabular}

FIT functioned to show the total variant of all variables used in the model of this research. The standardization of FIT value ranged from 0 up to 1 . Based on the table above, the formed model was able to explain all the variables with a value of $0,735(73,5 \%)$ and the rest $26,5 \%$ was explained by the other variables.

AFIT (Adjusted Fit) is almost similar to R-squared adjusted if done on regression analysis. AFIT functioned to show the model ratio. A model with the largest AFIT was the model that could be chosen among the better models. According to the table above, AFIT on the model of this research was known as much as 0,634 - meaning that the variety which could be explained by the model was $63,4 \%$. It reflected that the value of AFIT obtained by the formed model has already been good.

Based on the test result, the feasibility of overall model in this research was measured by using GFI and SRMR, in which the GFl's value obtained was 0,571 and SRMR's value was 0,621 . The used model was a good fit (fit model) if the GFl's value was more than 0,900 showed that) and the SRMR's value ranged from 0,05-0,08. Based on the empirical data resulted from the questionnaires fulfilled by respondents, the test of hypotheses could be conducted. The recapitulation of hypotheses test results in this research is shown in Table 2.

Table 2 - The Recapitulation Table of Hypotheses Test Results

\begin{tabular}{|c|c|c|c|c|c|c|}
\hline Hypothesis & The Influence between Tables & Estimate & SE & CR & Decision on H0 & Remark \\
\hline H1 & Optimism $\rightarrow$ PEoU & 0.2046 & 0.0902 & $2.268^{*}$ & Ditolak & Significant \\
\hline H2 & Innovativeness $\rightarrow$ PEoU & 0.3603 & 0.165 & $2.1834^{*}$ & Ditolak & Significant \\
\hline H3 & Discomfort $\rightarrow$ PEoU & 0.0315 & 0.2051 & 0.1535 & Diterima & Not Significant \\
\hline H4 & Insecurity $\rightarrow$ PEoU & 0.0292 & 0.1064 & 0.2741 & Diterima & Not Significant \\
\hline H5 & Enjoyment $\rightarrow$ PEoU & 0.3978 & 0.1788 & $2.2252^{*}$ & Ditolak & Significant \\
\hline H6 & PEoU $\rightarrow$ Intention toUse & 0.8208 & 0.0621 & $13.2209^{*}$ & Ditolak & Significant \\
\hline
\end{tabular}

${ }^{*} \mathrm{CR}=$ significant at .05 level

According to Table 2 above, it was discovered that the total of the all hypotheses were 6 lines, covering 4 significant lines and 2 not-significant lines. The test result of hypotheses model is shown in Figure 2.

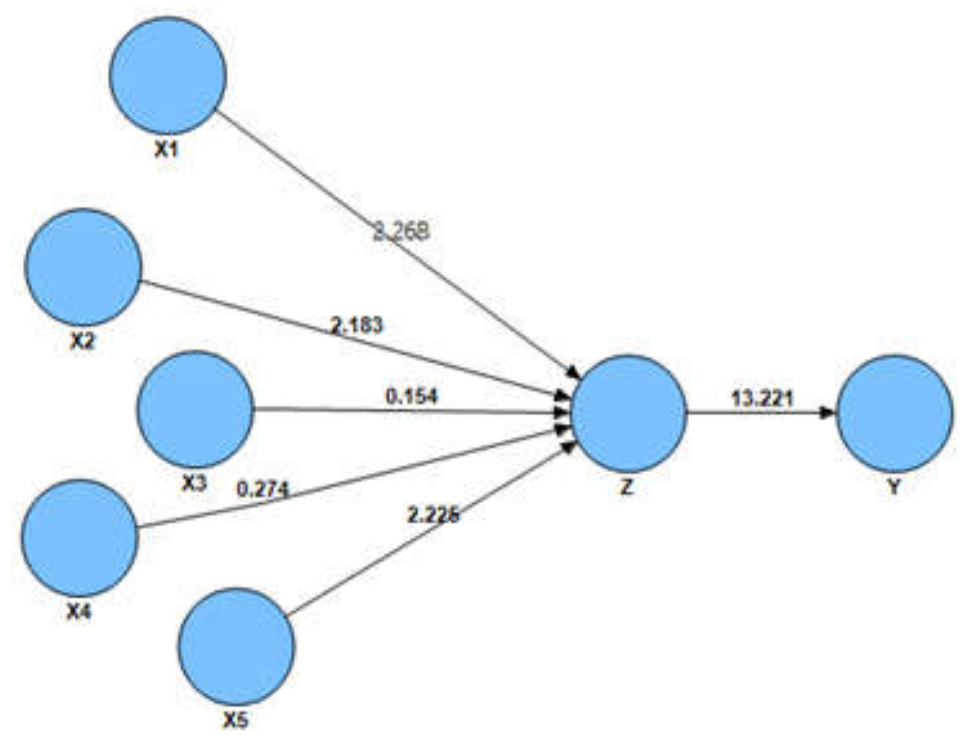

Figure 2 - The Test Result of Hypotheses Model 
Limitation of research. The limitation of this research was to the number of samples, which was only 30 UMKMs. The samples taken had less variation because there was only one sector of UMKM. This research did not notice or distinguish the size and complexity of the businesses proceeded by the respondents. It is expected that the next research will use more various samples, which do not only have one sector of UMKM and concern on the competitor pressure in taking a business decision.

\section{CONCLUSION}

An optimistic attitude owned by an individual will lead to a perceived ease of technology use due to a lack of anxiety emerging on the possibility of negative results. The higher innovative character owned by the manager/organizer/owner of a distro will increase the perceived ease of use in applying website technology and increase the potency on its adoption. This research describes that the feeling of discomfort in using technology will lead to a perception of difficulty in using it. The user's insecurity usually emerges due to the matter of his own security or privation. This will lead to an individual closed attitude toward a new technology and decrease the perceived ease of use in using a technology. The research results showed that the variable of enjoyment significantly influences and becomes the determinant of perceived ease of use. In this research, it is discovered that the distro managers or owners who perceive or assume that it is easy to use technology will intend to adopt the technology. According to this research, it is concluded that the measurement of TAM model focuses on the acceptance of technology - on how the user's behavioral intention or attitude in using technology. An increase of IT adoption by a creative industrial UMKM can be created if the actors of UMKM perceive the ease of technology use. Hence, in TR model, the result refers to the user's tendency in using a new technology to achieve his goals, while the measurement of TAM model is primary on the user's behavioral intention and attitude in using a technology. Thus, these models cannot be compared directly, but both can complement each other.

\section{REFERENCES}

1. Ajzen, I. 1991. The Theory of Planned Behavior, Organizational Behavior and Human Decision Processes, Vol. 50, 179-211.

2. Ajzen, I. and Fishbein, M. 1980. Understanding Attitudes and Predicting Social Behavior. Englewood Cliffs, NJ: Prentice-Hall.

3. Bandura, A., and Cervone, D. (1986). Differential Engagement of Self-reactive Influences in Cognitive Motivation. Organizational Behavior and Human Decision Processes, Vol. 38, pp. 92-113.

4. Davis, F.D. 1986. A Technology Acceptance Model for Empirically Testing new End-User Information Systems: Theory and Results. Doctoral dissertation. Sloan School of Management, Massacusetts Institute of Technology.

5. Davis, F.D., 1989. Perceived Usefulness, Perceived Ease of Use and User Acceptance of Information Technology. MIS Quarterly, Vol. 13, No. 3, Hal. 319-339.

6. Davis, F.D., 1993. User Acceptance of Information Technology: System Characteristics, User Perception and Behavioral Impacts. International Journal of Man-Machine Studies. Vol. 38, No.3, Hal. 475-487.

7. Davis, F.D., Bagozzi R.P., and Warshaw, P.R. 1989. User Acceptance of Computer Technology: A Comparison of Two Theoretical Models. Management Science, Vol. 35 No.8, pp.982-1003.

8. Fishbein, M. dan Ajzen, I. 1975. Belief, Attitude, Intention and Behavior: An Introduction to Theory and Research, Reading, MA: Addison-Wesley.

9. Godoe, P. \& Johansen, T.S., 2012. Understanding adoption of new technologies: Technology readiness and technology acceptance as an integrated concept. Journal of European Psychology Students. Vol 3, Hal. 38-52. 
10. Hwang, H. dan Takane Y., 2004, Generalized Structured Component Analysis, Psychometrika, Vol. 69, hal. 81-99.

11. Hartono, Jogiyanto, 2007. Model Kesuksesan Sistem Teknologi Informasi. Yogyakarta: Andi.

12. Kim, H.W., Chan, H.C., and Gupta, S., 2005. Value-based Adoption of Mobile Internet: An Empirical Investigation. Decision Support Systems, Vol. 43, pp. 111-126.

13. Lam, S. Y., Chiang, J., \& Parasuraman, A., 2008. The effects of the dimensions of technology readiness on technology acceptance: An empirical analysis. Journal of Interactive Marketing, 22 vol (4), 19-39.

14. Lefebvre, L., Harvey, J., dan Lefebvre, E. (1991). Technological experience and the technology adoption decision in small manufacturing firms. R\&D Management, Vol. 21(3), 241-249

15. Lin, C.H., 2010. Consumer Adoption of E-Service: Integrating Technology Readiness with the Theory Acceptance Model. Journal of Business, Vol. 4, No.6, pp. 3556-3563.

16. Lin, C.H., Shih, H.Y. and Sher, P.J., 2007. Integrating Technology Readiness Into Technology Acceptance: The TRAM Model. Psychology and Marketing, 24 (July 2007), pp. 641-657.

17. Parasuraman, A., 2000. Technology Readiness Index (TRI): A Multiple-Item Scale to Measure Readiness to Embrace New Technologies. Journal of Service Research, Vol. 2 No.4, pp. 307-320.

18. Parasuraman, A. \&. Colby, C.L., 2001. TechnoReady Marketing: How and Why Customers Adopt Technology The Free P., Australia: Simon and Schuster AU.

19. Pavic, S., Koh, S.C.L., Simpson, M. and Padmore, J., 2007. Could e-Business Create a Competitive Advantage in UK SMEs? Benchmarking: An International Journal. Vol. 14(3), 320-351.

20. Rahmana, Arief. 2009. Peranan Teknologi Informasi Dalam Peningkatan Daya Saing Usaha Kecil Menengah.Makalah disajikan dalam Seminar Nasional Aplikasi Teknologi Informasi 2009 (SNATI 2009), Yogyakarta, 20 Juni 2009. (Online), (http://directory.umm.ac.id/SI_UKM/1033-1045-1-PB.pdf), diakses 19 April 2016.

21. Rita Walczuch, J. Lemmink. and S. Streukens., 2007 . The effect of service employees' technology readiness on technology acceptance. Information \& Management, Vol. 44, pp. 206-215.

22. Seungjae Shin, and Won-jun Lee., 2014. The Effects Of Technology Readiness And Technology Acceptance On NFC Mobile Payment Services In Korea. The Journal of Applied Business Research, Volume 30, Number 6, pp. 1615-1625.

23. Solimun, 2012,. Permodelan Persamaan Struktural Pendekatan Generalized Structure Company Anlysis (GSCA) \& Analisis Variabel dan moderasi. Lab. Statistika FMIPA UNIBRAW. Malang.

24. Thong, J., 1999, Intergrated Model of Information System Adoption in Small business. Journal Of Management Information Systems, Vol. 15, pp.187-214.

25. Venkantesh, V., Morris, M.G., Davis, G.B., dan Davis, F.D. 2002. User Acceptance of information Technology: Toward a Unified View, MIS Quarterly, Vol. 27, No.3, pp. 425478.

26. Venkatesh, 2000. Determinants of Perceived Ease of Use: Integrating Control, Intrinsic Motivation, and Emotion into the Technology Acceptance Model. Information Systems Research Informs, Vol. 11, No. 4, pp. 342-365.

27. Walczuch, R., Lemmink, J., and Streukens, S., 2006. The Effect of Service Employees' Technology Readiness on Technology Acceptance Information and Management, Vol. 44, No.2, pp. 206-215.

28. Westland, J.C. and Clark, T.H.K., 2000. Global Electronic Commerce: Theory and Case Studies, MIT Press, Cambridge, M.A.

29. White, R. W., 1959. Motivation reconsidered: The Concept of Competence, Psychological Review, Vol. 66, pp. 297-335. 